\title{
Physical Properties and Chemical Compositions of Raw Cow Milk in Milk Shades Around Addis Ababa, Ethiopia
}

\author{
Zerihun Asefa, Getenesh Teshome \\ Ethiopian Institute of Agricultural Research P. O. Box 2003. Addis Ababa, Ethiopia
}

\begin{abstract}
Milk has an important diet for humans and animals. The aim of this study was to evaluate the physical property and chemical composition of raw cow's milk in central highlands of Ethiopia. Raw milk samples of 240 were collected from four sites of Wolmera, Selale, Sebeta, and Debrezeit for physical and chemical composition analysis. Physical parameters of $\mathrm{pH}$, titratable acidity, specific gravity, freezing point and chemical composition of total solids, protein, fat, ash and lactose were tested in this study. The result showed that there is no significant $(\mathrm{P}>0.05)$ difference in total solid and protein content among study site. The fat content was significantly higher in sample from Welmera and samples collected from Debrezeit were significantly higher lactose, ash, and solid non-fat content. Specific gravity and freezing point were no significant difference among the four study site. Milk samples of significantly higher $\mathrm{pH}$ were observed in Wolmera and Selale and significantly higher titratable acidity was observed in milk samples from Sebeta. All the chemical composition of total solid, fat, protein, Ash, lactose and solid non-fat were fit with Ethiopian standard. Among the tested physical property-specific gravity and freezing point were fit with Ethiopian standard and titratable acidity of milk from all sites were above Ethiopian standard. $\mathrm{PH}$ of the samples from all locations was lower $\mathrm{pH}$ than Ethiopia standard. Titratable acidity was higher than Ethiopian standard and $\mathrm{pH}$ was lower than Ethiopian standard. This is an indication that the milk was not fresh and develop acid due to lactose fermenting microbes in the milk and not suitable for pasteurization or processing. Keywords: Physical property, Chemical property, cow milk
\end{abstract}

DOI: $10.7176 /$ JNSR/9-19-04

Publication date:October $31^{\text {st }} 2019$

\section{Introduction}

Milk is the natural product obtained from the secretion of the mammary gland of lactating mammals. It is a highly nutritious substance which contains macro and micronutrients of fats, proteins, carbohydrates, vitamins, minerals and active compounds having a role in health protection (Merwan et al., 2018). Milk protein, fat, and lactose are an important source of energy. One gram of milk fat gives $9.3 \mathrm{Cal}$ and one gram of protein and lactose gives 4.1 cal.

Cow milk is the utmost used up in the world followed by that of goat, camel, and donkey(Cisse et al., 2019). In Ethiopia, cows contribute around $95 \%$ of the total annual milk produced in the country (CSA, 2010).

Physical properties and chemical compositions of milk were the indicators of qualities of milk with the sanitary standard (Haftu Kebede et al., 2018). The physical properties of milk were the specific gravity, freezing point, acidity and $\mathrm{pH}$ of the milk. These parameters were an indication of the standard and nutritional quality of milk. Specific gravity and freezing point were important parameters of indicative of the milk adulteration(Teklemichael Tesfay et al., 2015). In Ethiopia most milk collection centers and cooperatives are inspecting the quality of milk using physical properties of specific gravity and alcohol test for their freshness during milk collection. Titratable acidity and $\mathrm{pH}$ were also helped to test the quality of milk for processing in milk factory. The chemical composition of cow milk was its total solid, protein, fat and total mineral content. Chemical composition of cow milk is varying depends on the lactation stage, milking time, feed and breed. The density of milk depends on the chemical composition as well as the quality of milk. Physical properties of milk were the freezing point, density, Titratable acidity and $\mathrm{pH}$ which may deviate from normal rang depends on the storage condition and quality of milk.

\section{Material and methods \\ Study area}

The study was conducted in Wolmera, Selale, Sebeta, and Debrezeit of central Ethiopia.

\section{Sample collection and handling}

Raw cow milk of 240 milk samples was collected randomly from households of four sites Wolmera (60), Debrezeit (60), Selale (60), and Sebeta (60) in the central of Ethiopia. The sample was collected in the morning at the milk collection center from individual household farm before providing to milk collectors. Milk samples of $200 \mathrm{ml}$ were taken through homogenizing using sterile polytletene bottles and stored in ice box to deliver to Holeta dairy research laboratory for analysis. The samples were analyzed within 4hours of collection. 


\section{Analysis of physical properties and chemical composition}

The physical properties of specific density, $\mathrm{pH}$, freezing point and chemical composition of total solids, protein, fat, solid non-fat and lactose content were tested using lactoscan LAC-SPA -19578

(Musaad et al., 2013; Ruqyia et al., 2016). In detail the milk sample was homogenized by turn up down the sample bottle. The lactoscan was cleaned with lactoscan cleaning acid and alkaline and rinsed with distilled water three times. The $\mathrm{pH}$ of lactoscan was also calibrated using standard buffers of $\mathrm{pH} 4.00$ and 7.00 . Then $25 \mathrm{ml}$ samples were taken in the sample tube and put in the sample holder one at a time with the analyzer in the recess position. Then when the starting button activated, the analyzer sucks the milk, makes the measurements, and returns the milk in the sample tube and the digital indicator shows the specified results of freezing point, density, pH, and chemical composition of fat, protein, lactose, and solid not- fat (Shaker et al., 2015; Ruqyia et al., 2016).

\section{Total minerals (\% Ash)}

Total mineral (Ash) content was determined following standard methods for the examination of dairy products (Michael Wehr and Joseph F. Frank, 2004). Milk sample of 3g was weighed in pre-dried, cooled crucible and ignited in a muffle furnace of $550^{\circ} \mathrm{C}$ for five hours. They are cooled in a desiccator and their weight was recorded. The percent of ash was calculated as:

$$
\begin{array}{r}
\% \mathrm{Ash}=\frac{\mathrm{W} 3-\mathrm{W} 1}{\mathrm{~W} 2} \times 100 \quad \text { where; } \mathrm{W} 3=\text { weight of crucible plus Ash, } \\
\mathrm{W} 1=\text { weight of the crucible } \\
\mathrm{W} 2=\text { weight of the sample }
\end{array}
$$

\section{Titratable acidity}

The titratable acidity of the milk sample was tested following the standard methods of AOAC, 2005. Milk samples of $10 \mathrm{ml}$ were added into a $100 \mathrm{ml}$ white crucible and 3-4 drops of $0.5 \%$ phenolphthalein indicators were added using pasture pirate and stay for two minutes. After two minutes it was titrated with standard $0.111 \mathrm{~N}$ sodium hydroxide until a faint pink color persists for 10 seconds. The titratable of the sample was calculated as:

$\%$ Titratable acidity $=\frac{\mathrm{ml} \text { of } 0.11 \mathrm{~N} \mathrm{NaOH} \times 0.009 \mathrm{ml}}{\mathrm{ml} \text { of the sample used }} \times 100$

\section{Statistical analysis}

The data were analyzed using analysis of variance by SAS version 9.0. The results were expressed as mean \pm standard deviation. The difference between the means was calculated using least significant difference Tukey's test and $\mathrm{p}<0.05$ was considered statistically significant.

\section{Result and discussions}

The chemical composition of total solids, protein, fat, total mineral (Ash), lactose and solid non-fat of milk samples collected from each location were demonstrated in Table 1. Milk chemical composition was important parameters, which indicates the nutritional qualities of milk. Milk having high total solids has high fat, protein and casein content. In this study, the results of analysis of variance showed that there is a significant difference in total solid content among these study sites. Higher total solid of $13.404 \%$ in Wolmera and lower total solid content of $11.083 \%$ in Selale milk shade was observed. Related result of $13.40 \%$ and $12.575 \%$ were reported by Teshome et al., (2015) and Tecklemikael et al., (2015) respectively. Similar results of 13.48, 13.07 and $13.15 \%$ total solid were also reported by Ayisheshim et al., 2015, Deresse et al., 2008 and Asaminew et al., 2000, in milk sample from Western Amhara, Western Shewa, and Bahir Dar milk shades respectively. The result of this study also revealed that the total solid of all sites were fall within the quality standard of Ethiopia.

The protein content of milk sample from every four sites ranged from $3.08 \%$ to $3.28 \%$. However, there is no significant difference in protein content among the study site. This result is in line with $3.12 \%$ reported by Dehinenet et al., 2013 and lower than 3.67, 3.4 and 3.34 \% reported by Deresse et al., 2008, Haftu et al., 2013 and Ayisheshim et al., 2015, in cow milk of Western Shewa, Southern Ethiopia and Western Amhara region respectively. This variation may be due to genetic variability of milking cow or environmental factors like feed, lactation stage, milking interval, season, location, etc. However, the protein content found in this study was within the quality standard of Ethiopia and minimal milk protein content of $2.73 \%$ recommended by FDA (Raff et al., 2011)

In this study the fat content of milk samples was significant $(\mathrm{P}<0.05)$ difference among location. Significantly higher fat content $4.87 \%$ was observed in Wolmera and followed by milk samples from Sebeta site (4.8\%). Among each study site, a significantly lower fat content of $2.42 \%$ was observed in Selale. Similar results were reported by Gemechu et al., (2015) who reported that cow milk fat content of 4.25 in cow milk from producer and market in Shashemene town of eastern Ethiopia. The fat content of 4.28 is also reported by Hamad et al., (2015).On the other hand relatively, higher fat content of $6.01,6.024$, and 8.6 were reported by Gurmessa et al., 2015, Teshome Gemechu et al., (2016) and Legesse et al., (2017) in cow milks from Borena zone, Bench Maji-Zone and Somali 
Regional State of Ethiopia respectively. This variability might be due to genetic factor (breed of milking cow) or other environmental factors like feed, lactation stage age of animal, etc. On the other hand high milk-producing cow was low-fat content. However except milk from Selale milk shade all the study site milk have fit with Ethiopian raw cow milk standard.

The total mineral content of the milk ranges from 0.69 to 0.74 among study site. The ash content of each location has a significant $(\mathrm{p}<0.05)$ difference among locations. The significantly higher ash content of $0.74 \%$ was observed in milk samples from Debrezeit and lower ash content of $0.69 \%$ was observed in Sebeta. However, all sites milk was within the Ethiopia standard range. Similar results of $0.69,0.76$ and 0.82 from producer and market milk was reported by Hamad et al., 2015, Teshome Gemechu et al., 2015 and Gurmessa Terefa et al., 2015 respectively

Table 1 Mean value of Chemical composition of milk samples from each study sites

\begin{tabular}{|c|l|l|l|l|l|l|}
\hline Location & \multicolumn{1}{|c|}{ Total solid } & \multicolumn{1}{|c|}{ Protein } & \multicolumn{1}{c|}{ Fat } & \multicolumn{1}{c|}{ Ash } & \multicolumn{1}{c|}{ Lactose } & \multicolumn{1}{c|}{ SNF } \\
\hline Wolmera & $13.404 \pm 1.06^{\mathrm{a}}$ & $3.10 \pm 0.25^{\mathrm{a}}$ & $4.87 \pm 0.97^{\mathrm{a}}$ & $0.71 \pm 0.05^{\mathrm{ab}}$ & $4.72 \pm 0.25^{\mathrm{ab}}$ & $8.53 \pm 0.46^{\mathrm{ab}}$ \\
\hline Selale & $11.083 \pm 1.07^{\mathrm{b}}$ & $3.17 \pm 0.23^{\mathrm{a}}$ & $2.42 \pm 0.26^{\mathrm{c}}$ & $0.71 \pm 0.05^{\mathrm{ab}}$ & $4.76 \pm 0.34^{\mathrm{ab}}$ & $8.66 \pm 0.61^{\mathrm{ab}}$ \\
\hline Sebeta & $12.858 \pm 1.05^{\mathrm{a}}$ & $3.08 \pm 0.27^{\mathrm{a}}$ & $4.48 \pm 0.22^{\mathrm{ab}}$ & $0.69 \pm 0.06^{\mathrm{b}}$ & $4.63 \pm 0.4^{\mathrm{b}}$ & $8.38 \pm 0.74^{\mathrm{b}}$ \\
\hline Debrezeit & $12.797 \pm 1.05^{\mathrm{a}}$ & $3.28 \pm 0.49^{\mathrm{a}}$ & $3.81 \pm 0.87^{\mathrm{b}}$ & $0.74 \pm 0.11^{\mathrm{a}}$ & $4.95 \pm 0.7^{\mathrm{a}}$ & $8.99 \pm 1.25^{\mathrm{a}}$ \\
\hline ES & $10.50-14.50$ & $2.90-5.0$ & $2.50-7.0$ & $0.60-0.90$ & $1-10$ & $>8.0$ \\
\hline
\end{tabular}

Where $\mathrm{SNF}=$ Solid non-fat; $\mathrm{ES}=$ Ethiopian Standard

The lactose content of the milk sample from Debrezeit was significantly higher than other locations. There is no significant $(\mathrm{P}>0.05)$ difference in Selale and Wolmera milk shade. Relatively least lactose content of 4.63 was observed in Sebeta milk shade Table 1. The Lactose content of the entire site was within Ethiopian standard. Related results of 4.47, 4.91, and 4.69 were reported by Hamad et al., 2015, Legesse et al., 2015, Gurmessa Terefa et al., 2015, Teshome Gemechu et al., 2015 in raw cow milk collected from producer and market. On the other hand cow milk of lower fat content of 3.79 was reported by Estifanose Hawaz et al., 2015 in Harar milk shade of Ethiopia. This variability might be due to genetic or environmental factors.

The SNF of milk samples was a significant difference among each study sites. Significantly higher SNF of 8.99 was observed in Debrezeit and relatively minimum SNF milk was observed in milk of Sebeta milk shade. Similar results of 8.53 and 8.9 were reported by Hamad et al., 2015 and Teshome Gemechu et al., 2015. Ethiopian standard recommends raw milk should SNF of greater than 8.0 present and the SNF in this test were fit with the standard.

Table 2: Physical properties of milk sample of each location.

\begin{tabular}{|l|l|l|l|l|}
\hline Location & $\begin{array}{l}\text { Specific gravity } \\
\text { Mean } \pm \text { SD }(\text { in g/ml })\end{array}$ & $\begin{array}{l}\text { Freezing point } \\
\text { Mean } \pm \text { SD }\end{array}$ & $\begin{array}{l}\mathrm{pH} \\
\text { Mean } \pm \text { SD }\end{array}$ & $\begin{array}{l}\text { TA } \\
\text { Mean } \pm \text { SD }\end{array}$ \\
\hline Wolmera & $1.029 \pm 0.001^{\mathrm{a}}$ & $-0.554 \pm 0.035^{\mathrm{a}}$ & $6.53 \pm 0.13^{\mathrm{a}}$ & $0.19 \pm 0.02^{\mathrm{b}}$ \\
\hline Selale & $1.030 \pm 0.002^{\mathrm{a}}$ & $-0.546 \pm 0.044^{\mathrm{a}}$ & $6.55 \pm 0.29^{\mathrm{a}}$ & $0.24 \pm 0.03^{\mathrm{a}}$ \\
\hline Sebeta & $1.029 \pm 0.003^{\mathrm{a}}$ & $-0.542 \pm 0.058^{\mathrm{a}}$ & $6.17 \pm 0.65^{\mathrm{b}}$ & $0.23 \pm 0.07^{\mathrm{ab}}$ \\
\hline Debrezeit & $1.031 \pm 0.004^{\mathrm{a}}$ & $-0.578 \pm 0.085^{\mathrm{a}}$ & $6.02 \pm 0.5^{\mathrm{b}}$ & $0.25 \pm 0.02^{\mathrm{a}}$ \\
\hline ES & $1.026-1.032$ & -0.547 to -0.590 & $6.6-6.8$ & $0.1-0.17$ \\
\hline
\end{tabular}

Where $\mathrm{TA}=$ titratable acidity; $\mathrm{pH}=$ the potential of hydrogen ion concentration.

In this study, the physical property of specific gravity and freezing point of the milk samples from each study site were no significant $(\mathrm{P}>0.05)$ difference. Similar results of 1.028, 1.0312, 1.030 and 1.030 were reported by Teshome Gemechu and Tesfaye Amene 2015, Mohamed et al., 2010, Teshome Gemechu et al., 2015, Teklemichael Tesfay et al., 2015 respectively. The specific gravity of all the site were within Ethiopian Standard of $1.026-1.032$ and indication of free of adulterations.

The Titratable acidity was another important parameter of indication of the development of acid-producing microbes from lactose fermentation in the milk as well as an indicator of freshness of milk. According to Ethiopian standard normal fresh milk has titratable acidity of 0.1 to $0.17 \%$. However, in this study, titratable acidity ranges from 0.19 to $0.25 \%$. Higher titratable acidity of $0.25 \%$ was that of Debrezeit site and lower titratable acidity of $0.19 \%$ was that of Wolmera site Table 2 . This result indicates that the milk collected was no fresh milk, it developed acidity due to growth of acid-producing microorganisms as a result of inappropriate storage of milk. According to this study milk from all site of study were sub-standard of Ethiopian standard. Related results of 0.25 , 0.215, 0.29 and $0.22 \%$ were reported by Eklemichael Tesfeye et al., 2015, Leggese et al., 2017, Teshome Gemechu et al., 2015, and Gurmessa Terfa et al., 2015 respectively in cow milk from producer and market.

The pH has a significant difference between each study site. Significantly lower pH of 6.02 and 6.17 was observed in Debrezeit and Sebeta milk shade. Milk from Wolmera and Selale were $\mathrm{pH}$ of cloth to normal $\mathrm{pH}$ range. However, all milk collected from the four sites was $\mathrm{pH}$ of lower than Ethiopian standards of 6.60 to 6.80. This deviation from normality is an indication that the milk has not fresh and stored in an inappropriate temperature which causes acid development from lactose fermentation and lowers the $\mathrm{pH}$ of the milk. Similar results of 6.39 , 
6.32 and 6.195 were reported by Gurmessa Terfa et al, 2015, Teshome Gemechu et al., 2015, and Legesse et al., 2017 , respectively in milk from farms and market.

The freezing point of milk was affected by soluble constituents in milk like lactose and minerals. Protein and fat have no effect on freezing point of milk. According to Ethiopian standard fresh cow milk freezing point were -0.547 to -0.590 . Among the study site milk sample collected from Debrezeit and Wolmera were fit Ethiopian Standard and milk from Sebeta and Selale were sub-standards of Ethiopian standards. Related results of -0.559 were reported by G. Dehinenet et al., 2013 in major milk shade of Amhara and Oromia, Ethiopia. The freezing point of milk from Selale and Sebeta were sub-standard of Ethiopian standard. They have lower freezing point which might be due to adulteration with other substances.

\section{Conclusion}

Milk chemical composition was an indicator of the quality of milk for processing to other dairy products like butter, yogurt, cheese and the like. So that milk collected from all sites were fit with Ethiopian standard for raw whole milk. The specific gravity and freezing point was a parameter for quality and indicators of milk adulteration with other substrates like water. According to this study milk from these study site were relatively lower $\mathrm{pH}$ and higher titratable acidity than the standard these may result from clotting during pasteurization or heating and not suitable for pasteurized milk processing factory. Titratable acidity is an important parameter for verifying the freshness of milk. Milk having high titratable acidity has poor quality for pasteurization.

\section{References}

AOAC (2005). "Official methods of analysis". The association of official analytical chemists. $16^{\text {th }}$ edition. North Fredrick Avenue Gaithersburg, Maryland, USA.

Asaminew Tassew (2007) Production, handling, traditional processing practices and quality of milk in Bahir Dar milk shed area. MSc thesis, Alemeya University, Ethiopia.

Aysheshim B, Fekadu B, Mitiku E. (2015). Chemical composition and microbial quality of cow milk in urban and pre-urban area of Dangila town Western Amhara Region, Ethiopia. Global J Dairy Farm Milk Prod 3(1), 081-085.

Cisse H, Muandze-Nzambe JU, Somda NS, Sawadogo A, Drabo SM, Tapsoba F, Zongo C, Traore Y, Savadogo A. (2019). Assessment of safety and quality of fermented milk of camels, cows, and goats sold and consumed in five localities of Burkina Faso. Veterinary World, 12(2), 295-304.

CSA. (2010). Agricultural Sample Survey, Livestock, Poultry and Beehives population (private peasant holdings). Federal Democratic Republic of Ethiopia Central Statistical Authority (CSA), Addis Ababa, Ethiopia.

Dehinenet G, Mekonnen H, Ashenafi M, Emmanuelle G (2013). Determinants of raw milk quality under a smallholder production system in selected areas of Amhara and Oromia National states Ethiopia. Agric Biol, J. 4(1), 84-90.

Derese T (2008). Present situation of urban and peri-urban milk production and quality of raw milk produced in west Shoa zone, Oromia Region, Ethiopia. Thesis Haramaya University, Ethiopia.

Use the "Insert Citation" button to add citations to this document.

Gurmessa Terfa Debela, Mitiku Eshetu, and Alemayehu Regassa. (2015). Physico-chemical qualities of raw cow milk in Ethiopia. The case of Borana zone, Yabello District. Glob. J. Dairy Farm. Milk Prod. 3(2), 086-091.

Haftu Kebede and Degnet $\mathrm{H}$ Meskel, (2018). Determination of Adulteration and Chemical Composition of Raw Milk Sold in Hossana Town, South Ethiopia. Dairy and Vet Sci J.6 (5), 001-007.

Hamad, M. N. E.1 and Baiomy, A. A. (2015). Physical properties and chemical composition of cow's and buffalo's milk in Qena governorate.

K S, Degnet H M.(2018). Determination of Adulteration and Chemical Composition of Raw Milk Sold in Hossana Town, South Ethiopia. Dairy and Vet Sci J. 6(5),

Legesse A, Adamu F, Alamirew K and Feyera T.( 2017). A Comparative Study on the Physicochemical Parameters of Milk of Camel, Cow, and Goat in Somali Regional State, Ethiopia. Chem Sci J. 8(4), 171- 176.

Merwan Ahmedsham, Nezif Amza and Metekia Tamiru.(2018). Review on milk and milk product safety, quality assurance and control. Int. J. Livestock Prodn. 9(4), 67-78.

Michael Wehr and Joseph F. Frank (2004). standard Methods for the Examination of Dairy Products $17^{\text {th }}$ Edition. American Public health Association.

Musaad, A., Faye, B., and Al-Mutairi, S. (2013). Seasonal and physiological variation of gross composition of camel milk in Saudi Arabia. Emir. J. Food Agric. 25, 618-624.

Raff H (2011). Market implications of changing fat content of milk and dairy products, fat content and composition of animal products. J Food Sci Technol. 5(2), 6-17.22.

Shaker, E. M., Abd-Alla, A.-E. A., and Elaref, M. Y. (2015). Detection Of Raw Buffalo's Milk Adulteration In Sohag Governorate. 61, 38-45.

Tassew A, Seifu E. (2011). Microbial quality of raw cow's milk collected from farmers and dairy cooperatives in 
Bahir Dar Zuria and Mecha district, Ethiopia. Agric. and Biol. J. North Am.

Teklemichael Tesfay, Ameha Kebede, Eyassu Seifu (2015). Physico Chemical Properties of Cow Milk Produced and Marketed in Dire Dawa town, Eastern Ethiopia. Food Science and Quality Management.42, 56-62.

Teshome Gemechu and Tesfaye Amene (2016). Physicochemical Properties and Microbial Quality of Raw Cow Milk Produced by Smallholders in Bench Maji-Zone, Southwestern Ethiopia. Food Science and Quality Management. 54, 47-54.

Teshome Gemechu, Fikadu Beyen, and Mitiku Eshetu. (2015). Physical and chemical qualities of raw cow milk produced and marketed in Shashamane town, Southern Ethiopian. J.Food Agric. Sci. 5(2), 7-13. 